\title{
VÁRZEAS, OPERÁRIOS E FUTEBOL: UMA OUTRA GEOGRAFIA
}

\author{
GILMAR MASCARENHAS DE JESUS \\ Universidade do Estado do Rio de Janeiro
}

\section{INTRODUÇÃO}

$\mathrm{Na}$ condição de elemento central na cultura brasileira, o futebol tem sido capaz de gerar objetos marcantes na paisagem urbana, como os estádios, dotados de notável centralidade funcional e simbólica. Também se espacializa na proliferação de campos de futebol e na intensa apropriação de espaços públicos (ruas, praças, parques, praias) para a prática informal deste esporte. Não obstante tamanha expressão espacial, o futebol não tem figurado nos estudos urbanos empreendidos pela geografia brasileira ${ }^{1}$. Tampouco figura com satisfatória atenção em outras disciplinas que estudam a sociedade:

Nas Ciências Sociais no Brasil, até recentemente, muito pouco se refletiu a respeito das dimensões sociológicas, culturais e politicas de uma série de fenômenos (...) Assim é que as questões que podem ser sugeridas por análises do enorme espectro de representações e relações sociais colocadas em operação pelo futebol no Brasil, permanecem estranhas na academia até, pelo menos, a década de 70, limitando-se a algumas raras incursões isoladas ou a compor lateralmente análises mais amplas que buscavam interpretações da realidade brasileira (GUEDES, 1998:102).

Em síntese, cidade e futebol no Brasil perfazem um pífio encontro no plano intelectual: um jogo de 0x0, pobre em lances capitais. O panorama geral ainda é incipiente, embora promissor ${ }^{2}$.

Nosso objetivo neste trabalho é analisar o processo de popularização do futebol em São Paulo, verificando até que ponto este reflete características do lugar que o abriga. Trilhando o caminho da geografia urbana, tentaremos demonstrar como a cidade de São Paulo se antecipou a todas as demais no Brasil na adoção organizada do futebol, tanto na prática elitista quanto na sua posterior popularização. Pretendemos situar a evolução desta prática social em relação à dinâmica urbana, abrangendo o longo período que se estende aproximadamente entre 1890 e 1960. Para tal, o texto se divide em três segmentos: no primeiro, apresentamos o futebol como uma modalidade esportiva codificada no século XIX e que rapidamente se inseriu na cultura operária em formação (uma "religião leiga", diria Hobsbawm). A seguir, tratamos do pioneirismo paulistano no contexto nacional, adoção precoce do futebol que favoreceu sua posterior disseminação pela várzea; por fim, lidamos com o processo de popularização do futebol na cidade.

1 Os raros estudos se dirigem a temáticas mais amplas da vida urbana, conferindo ao futebol o breve papel de coadjuvante. Podemos enquadrar neste caso trabalhos como os de Odette Seabra (tese de doutorado, 1987) e André Martin (dissertação de mestrado, 1984): tendo como alvo a vida operária em bairros paulistanos outrora marcados pela presença da várzea, trazem à tona breves momentos do antigo futebol popular varzeano. Dignas de registro são as notas de Pierre Monbeig sobre o futebol na cidade de São Paulo (MASCARENHAS, 1999b). Mais recentemente, Odette Seabra (2000) vem investigando a inserção do futebol popular na vida de bairro.

$2 \mathrm{O}$ estudo do futebol como fenômeno social é relativamente recente no Brasil, e vem apresentando formidável crescimento, especialmente na década de noventa. Sobre futebol e cidade, merecem alusão os trabalhos de Reis Filho (1994), Roberto Da Matta (1982), Sevcenko (1992 e 1994), Paoli (1990), Antunes (1992), Damo (1998) e Pereira (2000). 


\section{A RELIGI $\tilde{A} O$ LEIGA DA CLASSE OPERÁRIA}

As regras de consenso da Football Association, estabelecidas em 1863 na cidade de Londres, foram sendo progressivamente aceitas e adotadas em diversas instituições, de forma que oito anos mais tarde foi criada a Copa da Inglaterra. Àquela altura dos acontecimentos, o futebol já deixara de ser um jogo exclusivo de estudantes no cumprimento particular das atividades curriculares, para tomar-se prática disseminada também pelos clubes, formados tanto pelas elites quanto por elementos da classe média urbana, a grande maioria ex-estudantes com interesse em continuar jogando futebol. E o bem sucedido esporte se revela um atraente espetáculo: alguns jogos na década de 1870 já atraíam público superior a dez mil pessoas, sobretudo nos acirrados confrontos entre as seleções nacionais de Inglaterra e Escócia ${ }^{3}$, O futebol estava iniciando sua longa transição do ideal atlético clássico para ingressar em definitivo no circuito da mercadoria.

Ao se tornar uma lucrativa e promissora indústria de entretenimento passivo para multidões, o futebol passou a aglutinar poderosos interesses comerciais que logo lhe atribuíram sentidos muito distintos daqueles até então vigentes, associados a uma pedagogia "mens sana in corpore sano". Com o advento do futebol-espetáculo, entra em cena um novo tipo de atleta, adestrado pois se dedica exclusivamente ao futebol, vivendo-o como profissão remunerada e socialmente cobiçada, e que por isso encara cada partida como uma batalha. Estes novos protagonistas ajudarão a tomar o futebol uma verdadeira paixão popular na Inglaterra no final do século XIX. Algo que Hobsbawm (1991:262) classificou como uma espécie de "religião leiga da classe operária"4.

A Inglaterra é o berço inconteste da revolução industrial, o que supomos guardar relação direta com sua primazia na "invenção" dos esportes modernos. Tornando exclusivamente o futebol, podemos detectar em sua configuração vários aspectos que o aproximam daquele nascente mundo fabril. Primeiramente, o trabalho em equipe, que a grosso modo diferencia a fábrica moderna da velha produção artesanal. Outra característica, resultante da ação articulada coletivamente, é a especialização individual. Um jogador de futebol assume determinadas funções relacionadas a sua posição no time e no campo de jogo, e deve nela se especializar, tal qual o operário numa linha de montagem ${ }^{5}$.

Observando as premissas do taylorismo (os princípios de "administração científica" de F.W. Taylor, para suprimir qualquer gesto inútil e otimizar a produção industrial), o sociólogo João Boaventura $(s / d)$, em artigo sugestivo, aponta quatro elementos do taylorismo presentes no futebol: a ênfase na velocidade, na especialização de poucas mas decisivas habilidades, na cronometragem e no trabalho em equipe ${ }^{6}$. Nilo Surubu (1963:171) vai além, ao afirmar que o futebol "não é mais que a imagem esportiva do trabalho nas fábricas", chegando a sugerir que até mesmo a expansão do socialismo no século XX tem vínculos com o êxito popular do futebol. Mas não precisamos recorrer a quase delírios para conferir os evidentes nexos entre a industrialização e a natureza do futebol e sua expansão ${ }^{7}$. Hobsbawm nos ajuda quando constata

3 Cf. Tony Mason (1980:139), que dedica um capítulo inteiro de seu livro ao estudo da multidão no futebol inglês, desde 1871 até 1915 .

4 Tony Mason (1980:32), estudioso no assunto, nos mostra a preocupação de um jornal em 1888, ao reconhecer que "os requisitos para o jogo são tão poucos e baratos que dele pode participar até o homem mais miserável”. De fato, improvisando facilmente as condições mínimas necessárias, as massas pauperizadas pelo capitalismo industrial se dedicaram com alegria ao futebol, e logo surgiram os talentos individuais, que despertariam interesse econômico nos agentes envolvidos com esta florescente indústria do entretenimento. Registre-se que em 1885 já existiam mais de mil clubes de futebol na Inglaterra (MASON, 1980:13).

5 Cada uma das onze posições numa equipe de futebol pressupõe, para ser bem desempenhada, um conjunto específico de habilidades e atributos. Neste sentido, um goleiro deve possuir elevada estatura, elasticidade, reflexo e concentração; um defensor (zagueiro) deve possuir força física, estatura, capacidade de prever e se antecipar às jogadas do ataque adversário e sobretudo bom senso de colocação no campo; um lateral-direito não pode obviamente ser canhoto (um lateral-esquerdo o deve), necessita vigor físico (para auxiliar o ataque) e mais habilidade que o zagueiro (a quem cabe basicamente "destruir" as investidas do adversário) para avançar com freqüência e fazer "cruzamentos", e a estatura não compromete seu desempenho; um jogador de meio-campo, que também prescinde da estatura, deve possuir boa visão de jogo, espírito de liderança, saber conduzir a bola e possuir excelente "passe”, para armar com inteligência e precisão as jogadas de ataque, (pois atua na chamada zona de raciocínio"); por fim, um atacante deve reunir velocidade, boa pontaria, estatura e força física (para disputar com os defensores adversários as "bolas aéreas") e sobretudo frieza e capacidade de resolução, pois, ao contrário do meio-campista, deve definir a jogada em fração de segundos. Defensores e atacantes devem "resolver" as situações rapidamente, mediante a escassez de tempo e espaço, ao contrário dos jogadores de meio-campo.

6 O autor salienta que Taylor tinha 29 anos quando o futebol inglês foi profissionalizado em 1885. Curiosamente, compara ainda o estádio à fábrica, o clube à gerência fabril e os operários aos jogadores, sendo os gols seus produtos e os espectadores os consumidores. Exagera talvez ao afirmar "o que é a tabela classificativa do campeonato senão a cotização do mercado capitalista do futebol?" (BOAVENTURA:9).

7 Buytendijk (1965:71) também observa que o "trabalho em equipe" do futebol se ajusta plenamente à era industrial, sendo por outro 
que "o mapa da Federação de Futebol era praticamente idêntico ao mapa da Inglaterra industrial" (1987:285). E vale observar que, não por acaso, São Paulo foi a primeira cidade no Brasil a popularizar o futebol.

Tomando, a partir das contribuições da nova história social inglesa, o universo da fábrica como pedagogia autoritária da valorização racional do tempo, podemos reencontrá-lo em diversos aspectos do futebol. Os jogadores devem obedecer estritamente às instruções do treinador (ter "disciplina tática"), sob pena de perder a vaga na equipe, pois trata-se de um empregado empenhado em produzir ao máximo e em respeitar a hierarquia dentro do clube, para manter seu provisório posto de trabalho, por muitos disputado. Sobre o uso racional do tempo, a velocidade é fundamental para superar o adversário e por um instante abrir valiosos "espaços" num campo ocupado estrategicamente por 22 atletas de alta mobilidade. Ainda o fator tempo se revela importante quando se sabe que, numa partida de futebol, ao contrário do basquete ou do futebol americano, os cronômetros funcionam sem interrupção, não se submetendo ao andamento do jogo. A duração de uma peleja não depende de contagem de pontos (como no voleibol, beisebol ou tênis), mas exclusivamente do frio e implacável cronômetro, tal qual na fábrica ${ }^{8}$. Talvez toda essa "pedagogia fabril" se manifeste mais concretamente no fato de inúmeros clubes terem surgido, desde o início da história do futebol, por iniciativa da gerência industrial".

Diversos autores, sobretudo os de inspiração marxista ${ }^{10}$, já realçaram o papel do futebol na formação e submissão da classe operária, como eficaz dispositivo no sentido de imbuir o trabalhador de senso de coletividade, de especialização, disciplina, hierarquia, competitividade e valorização do tempo cronometrado. Geralmente se critica o fato deste esporte, ao se "industrializar" (ter se tornado uma vigorosa indústria sob os interesses do capital), produzir alienação no torcedor (e portanto bloquear o avanço dos ideais revolucionários) e castrar do jogador a criatividade, espontaneidade, a alegria e a auto-determinação ${ }^{11}$. O futebol é também acusado de sustentar regimes totalitários, incutindo sentimentos militaristas e nacionalistas (SEBRELI, 1981). Se envereda aqui por uma discussão da maior relevância, mas neste momento apenas nos interessa frisar o quanto o futebol efetivamente participa da reprodução social da cidade e mantém com a industrialização nexos incontestáveis ${ }^{12}$.

Segundo ainda Hobsbawm, o futebol tornou-se o tópico principal na conversa social de bar, uma "língua franca" para todos os operários. Sustenta o autor que tal jogo se aproveitou do vácuo deixado pelas esferas comunitárias (a aldeia, a família, o bairro, a paróquia) em desagregação na cidade moderna (HOBSBAWM, 1991:170). São enfim as novas condições da vida urbana, a demandar novas tradições e a incorporar uma nascente classe operária, que contribuem para a popularização do futebol. Mas todo esse processo requer, como pré-requisito, a disponibilidade da informação "futebol". Veremos por conseguinte no próximo segmento que a cidade de São Paulo foi pioneira na adoção desta modalidade esportiva no Brasil, condição fundamental para que este jogo se espraiasse mais tarde pelas várzeas.

\section{SÃO PAULO: CIDADE PIONEIRA NO FUTEBOL BRASILEIRO}

Praticamente não há dúvidas de que o futebol foi introduzido na Argentina através de Buenos

lado incompatível (por isso inexistente) na Antiga Grécia, por sua cultura individualista e "estético-erótica"

8 Segundo Juan Villoro (1998:59), no futebol "el tiempo conserva su insistente capacidad de menguar el destino(...) ni siquiera un decepcionante $0 \mathrm{x} 0$ garantiza una prórroga".

9 No Brasil, o único estudo mais aprofundado sobre o futebol de fábrica pertence a Fátima Antunes (1992). Em nossa tese de doutorado, vimos que também no Rio Grande do Sul foram os principais centros fabris do início do século (Rio Grande e Pelotas) os primeiros a se destacar na prática do futebol, envolvendo inclusive vários clubes de fábrica.

10 Neste conjunto numeroso e de alta densidade crítica, gostaríamos de citar as abordagens afiadas de Gerhard Vinnai (1974), Juan Sebreli (1981) e mais recentemente a contribuição de Jean-Marie Brohm (1998), que alerta estar todo o planeta, via televisão, sendo "intoxicado" pelo rolo compressor do "império do futebol" (:63-4).

11 Em atitude radical, Roberto Ramos (1984) sugere enquadrar o futebol na concepção althusseriana de Aparelho Ideológico de Estado.

12 Certamente, não apenas a presença ostensiva da fábrica no mundo do trabalho justifica a popularização do futebol naquele contexto histórico. Hobsbawm adverte que a segunda metade do século XIX foi extremamente rica em inovações na cultura popular inglesa, e o autor inclui o futebol no leque de novas possibilidades de "entretenimento profissional" para o pobre trabalhador urbano. Em Outra obra (1987:288), o historiador inglês afirma que o hábito de torcer pelo clube de sua cidade (uma necessidade de novos vínculos identitários, em cidades com elevados índices de desenraizada população imigrante) propiciou a emergência de uma sólida "cultura masculina do futebol". (HOBSBAWM, 1989: 58). 
Aires; no Uruguai, por Montevideo; no Chile, por Valparaíso; na Itália, por Gênova e na França pelo porto normando de Le Havre ${ }^{13}$. No Brasil, entretanto, a imensidão territorial e a existência de numerosos portos dificulta localizar um único ponto no mapa para este fim $^{14}$. Embora nossa investigação aponte para a pluralidade de "portas de entrada" do futebol no Brasil, e que se reconheça a impossibilidade de localizar precisamente o momento e lugar de nossa primeira experiência futebolística, São Paulo pode resgatar seu velho emblema de "locomotiva nacional" e tomar para si o orgulho de ser o berço de tal esporte no Brasil. Foi sem dúvida a primeira cidade a organizar o futebol e vê-lo disseminado pelas ruas.

Nenhuma cidade brasileira apresenta tamanha precocidade na introdução do futebol como São Paulo ${ }^{15}$. Podemos afirmar que já no final do século passado tal esporte era praticado em clubes, empresas (capital inglês) e estabelecimentos escolares; que em 1896 o velódromo da família Prado $^{16}$, na Consolação, é reformado para abrigar partidas de futebol; que em 1902 a cidade organiza o primeiro campeonato de futebol do país. Segundo Mazzoni (1968), a primeira partida de futebol realizada no Brasil dentro das regras oficialmente estabelecidas na Inglaterra em 1863, ocorreu na Várzea do Carmo, entre as equipes inglesas São Paulo Railway e The São Paulo Gaz, em 14 de abril de 1895. Complementando este elenco de pioneirismo paulistano, resta frisar que o primeiro clube de futebol formado essencialmente por brasileiros foi o Mackenzie College, criado em 1898. A título de curiosidade, outros clubes "nacionais" foram criados em São Paulo na virada do século, mas nenhum sobreviveu, o que qualifica o Sport Club Rio Grande (RS), fundado em 1900, como mais antigo clube brasileiro de futebol em atividade. Mas não enquanto "berço do futebol" como se afirma não raramente na literatura esportiva do Rio Grande do Sul (MASCARENHAS, 2001).

No ano de 1905, o futebol era ainda desconhecido para a ampla maioria dos brasileiros, e bem poucas cidades no Brasil o praticavam com alguma regularidade. Em São Paulo, porém, ele já atraía grande interesse e até mesmo suscitava paixões que extrapolavam o âmbito esportivo. Rosenfeld cita o discurso fervoroso de Monteiro Lobato naquele ano, após assistir a concorridos duelos entre paulistanos e ingleses:

Essa luta tinha para a população de São Paulo um significado moral dez vezes maior do que a eleição para um presidente do Estado (...) O último goal do Paulistano provocou a maior tempestade de aplausos jamais conhecida em São Paulo (...) É desta espécie de homens que precisamos. Menos doutores, menos parasitas, menos bajuladores, e mais struggle-for-life. Mais homens, mais nervos, mais corpúsculos vermelhos, para que um Camilo Castelo Branco não possa repetir que ele tem sangue corrompido nas veias e farinha de mandioca nos ossos.(LOBATO, Apud ROSENFELD 1993: 79-80)

Neste mesmo ano de 1905, o Fluminense FC havia apenas deixado há pouco de ser o único clube carioca dedicado regulamente ao futebol. Em Porto Alegre, apenas Grêmio e Fussball encontravam-se a cada seis meses para um match. Somente Salvador, em todo o Brasil, possuía tal qual São Paulo um campeonato anual de futebol, iniciado naquele mesmo ano, entretanto sob a direção dos ingleses e disputado improvisadamente numa praça ${ }^{17}$, enquanto os paulistanos já contavam desde o início com um equipamento específico como o velódromo da Consolação. Indagar sobre as possíveis razões que levaram São Paulo a tomar a dianteira neste processo é o nosso objetivo principal neste momento. Podemos assim lançar algumas hipóteses preliminares.

São Paulo vivia um momento decisivo de explosão de crescimento urbano, quase quadruplicando sua população na última década do século XIX, sob o impulso fulminante da expansão de sua hinterlândia baseada no binômio ferrovia-cafeicultura (SINGER, 1974:53). A

13 Informações colhidas em autores diversos: Guttman (1994), Santa Cruz (1996), Mason (1995) e Outros.

14 Estudando o advento do futebol na Espanha, encontramos ali um caso semelhante ao brasileiro. Ver Mascarenhas, 2001a.

15 A literatura relativa à história do futebol paulistano é numerosa. Merecem consulta, dentre outros, os trabalhos de Mazzoni (1950), Caldas (1990), Antunes (1992 e 1998) e Fontenelle (1997). O jornalista Thomaz Mazzoni é reconhecido pela seriedade pela qual organizou os primeiros amplos arquivos documentais da história do futebol brasileiro, terreno aliás lamentavelmente pleno de afirmações de validade duvidosa.

16 No país que possui o maior parque de estádios de futebol do mundo e que apresenta-se repleto de "campinhos" por todo o seu ecúmeno, este pode ter sido o nosso primeiro "pedaço de chão" preparado e destinado especificamente à prática do futebol. Seria portanto a primeira espacialização concreta deste esporte em nosso território.

17 O primeiro campeão baiano de futebol é o Club Internacional de Cricket, composto exclusivamente por ingleses, que aliás fundaram a respectiva liga. O "campeonato" era disputado no antigo Campo dos Mártires. Informações colhidas na série de artigos "Memória do Futebol", de autoria do historiador Aloildo Pires, publicada no jornal A Tarde, de Salvador. 
"metrópole do café" (AZEVEDO, 1958; BRUNO, 1984) vive então uma febre de investimentos estrangeiros, e são muitos os estabelecimentos e colégios ingleses na cidade. Os ingleses criam seus clubes e praticam esportes, dentre eles aquele então na moda em sua terra natal: o futebol. $\mathrm{O}$ mais importante é que o fazem numa cidade que vivencia o frenesi da modernidade, o que significa dizer que São Paulo está aberta às inovações, está pronta para modernizar-se. Em outras palavras, nesta cidade, talvez mais do que em qualquer outra no Brasil, os ingleses estavam semeando o futebol em solo muito fértil ${ }^{18}$.

Podemos sugerir duas hipóteses para tentar explicar a razão pela qual São Paulo, na adoção do futebol, antecede o Rio de Janeiro (então a capital federal, de condição portuária, maior centro industrial e demográfico do país). Primeiramente, os cariocas já possuíam um esporte de relativa popularidade, o remo, que o futebol somente conseguiu destronar por volta de 1910 (MELO, 1999). Por outro, devemos considerar a modernidade paulistana. Se o Rio de Janeiro também se industrializa rapidamente, sua modernização se faz a partir de uma materialidade fundada em pesada herança colonial, expressa por exemplo no urbanismo, no ambiente dos títulos nobiliárquicos e no numeroso contingente de excluídos (a maioria ex-escravos), daí possivelmente oferecer maior resistência a determinadas inovações. Em São Paulo, o surto de crescimento se realiza sobre um território que era, em 1872, um pequeno núcleo "caipira" (o velho "burgo dos estudantes") de 31 mil habitantes, pronto para ser inteiramente reconstruído e ampliado sob as forças hegemônicas da nova ordem 'industrial. Acreditamos que esta cidade, embrião da metrópole frenética de que nos fala Sevcenko (1992), era naquele momento a que melhores condições possuía para assimilar inovações, e dentre elas o futebol.

Comparando as informações contidas em Sevcenko (1992:58) para o ano de 1919, com as que encontramos para o restante do Brasil, podemos ainda supor que São Paulo (acompanhada muito de perto pelo Rio de Janeiro) foi a primeira cidade a atrair grandes multidões aos estádios. Para finalizar este elenco de méritos paulistanos, afirmamos que com a inauguração do Estádio Municipal do Pacaembu em 1938, estava nascendo uma das principais tradições políticas do futebol brasileiro: a construção generalizada de estádios com recursos públicos ${ }^{19}$.

Até aqui lidamos com o chamado "futebol oficial". Resta observar como se difundiu o circuito informal desta atividade, no anonimato dos terrenos baldios da cidade.

\section{O FUTEBOL POPULAR E A CIDADE}

Desde os primeiros anos deste século, uma febre invadiu todas as ruas, quintais, portas de fábrica, terrenos baldios, e o que mais houvesse. Era o futebol. Esta foi a primeira grande festa do povo, fora da perspectiva da Igreja. (...) A sociabilidade de bairro foi enormemente enriquecida com o futebol. (SEABRA, 2000:14).

Vimos que em 1902 os paulistas organizam o primeiro campeonato de futebol no Brasil. No mesmo ano, surgem os primeiros campos de várzea, que logo se espalham pelos bairros operários (ANTUNES, 1992:19); e já em 1908/1910 a várzea paulistana congregava vários e concorridos campeonatos, de forma que São Paulo não é apenas pioneira nacional no futebol "oficial", mas também (e sobretudo) no "futebol popular". É nesta cidade que, não por acaso, surge em 1910 aquele que, dentre os grandes clubes do futebol brasileiro, foi o primeiro a se formar a partir de uma base popular: o Sport Clube Corinthians Paulista (NEGREIROS, 1992).

Inicialmente, o futebol varzeano era tomado como desordem, encontro de vadios a ser disciplinado ou mesmo perseguido pela polícia. A imprensa de época estabelece uma clara distinção entre o futebol das elites, elegante e bem organizado, e o futebol varzeano, como se fossem modalidades e práticas sociais completamente diferentes e até mesmo opostas ${ }^{20}$. O próprio

18 Os ingleses tiveram papel importante, mas não devemos esquecer, conforme salienta Antunes (1992), a influência dos jovens ricos que regressavam de estudos na Europa, entusiasmados com o futebol, e particularmente o esforço pessoal de Charles Miller, filhos de ingleses, em difundir tal esporte na cidade.

19 Tal prática, herdada do fascismo italiano e iniciada com o Estado Novo, atingiu seu auge durante o regime militar, particularmente no governo Médici (1969-1974). Ramos (1984:27) afirma que 70\% dos estádios brasileiros foram construídos com recursos públicos. Espelhando a ideologia fascista do gigantismo, e a política de fomentar espetáculos populares, freqüentemente tais estádios foram superdimensionados em sua capacidade, fato comum principalmente no Norte e Nordeste.

20 Foi generalizada, ao que parece, a resistência aristocrática à popularização do futebol nas cidades latinoamericanas, com suas elites desejosas de europeização e de afirmação de distinção social e afirmação de nobreza. Sobre o caso portenho, ver o artigo de Di 
Corinthians encontrou grande resistência para ingressar na liga oficial da cidade. Por volta de 1920, entretanto, a atividade já havia se disseminado a tal ponto que não havia como reprimi-la.

A difusão do futebol enquanto prática popular de entretenimento se insere na própria formação da classe operária paulistana, como elemento de sua cultura. Certamente, o grande número de imigrantes e operários contribuiu para a rápida popularização do futebol em São Paulo. Nas palavras de Fátima Antunes:

Da Várzea do Carmo, os campos se alastraram por toda a cidade, sobre tudo nos bairros operários, situados ao longo das estradas de ferro (...) A cidade vivia intensamente a experiência do trabalho fabril e passava a conhecer a necessidade imperativa de sociabilidade e lazer; sobretudo aos domingos. Os clubes de várzea mantinham equipes de futebol e promoviam atividades sociais (...) Além destes, tornavam-se comuns os clubes formados a partir de empresas, fábricas ou grupos profissionais. (ANTUNES, 1998: 92)

Estudo realizado pelo Conselho de Defesa do Patrimônio Histórico (COONDEPHAT, 1994) sugere que a partir da década de 1930 os bairros da cidade se relacionavam sobretudo através do futebol. Estudando o futebol varzeano, Odette Seabra (2000) colheu depoimentos que garantem a existência de muitas dezenas de campos de futebol na várzea paulistana por volta de 1940 e 1950 , e todos intensamente utilizados, enredando uma ampla sociabilidade entre os bairros. Parece ter sido a primeira cidade brasileira a se aproximar da impressionante febre futebolística que se espraiou no início do século em Buenos Aires (FRYDENBERG, 1999) e Montevideo (BUZZETI, 1969), cidades pioneiras no futebol sul-americano, e em menor grau em Santiago do Chile (SANTA CRUZ, 1996).

Vale registrar que este pujante "futebol informal" despertou interesse no geógrafo francês Pierre Monbeig, na década de 1940, e bem reflete a preocupação das elites e seu discurso da ordem em relação aos numerosos campos de várzea. Referindo-se, em tom de lamentação, ao mato que cresce rápido nos terrenos baldios ("à espera dos urbanistas"), especialmente nas várzeas da capital paulista, que "resistem ao loteamento", afirma Monbeig (1953:66) que tais zonas são "sobretudo paraíso de cães vadios (...) refúgio para cabanas de miseráveis, terreno do futebol improvisado para moleques (...) verdadeiras zonas entre os bairros residenciais". Mas ressalta sua fé no progresso implacável de São Paulo, afirmando a seguir que "tudo aquilo mingua ano após ano. No Pacaembu, a municipalidade construiu um estádio de linhas tão imponentes quanto harmoniosas" ${ }^{21}$. Fica evidenciado que para o autor o futebol comparece na paisagem urbana de forma ambígua. Por um lado, como prática informal de entretenimento ele representa o atraso e a pobreza persistentes. Por outro, o estádio é a maravilhosa obra coletiva que encarna plenamente a modernidade paulistana ${ }^{22}$.

O "progresso" capitalista não tardou a chegar e afetar os lugares consagrados pela cultura popular. A retificação dos rios Pinheiros e Tietê, a partir dos anos 1950, eliminou da paisagem urbana inúmeros campos de várzea (SEABRA, 1987), provavelmente mais de uma centena. Nas últimas três décadas, fatores diversos como expansão brutal do tráfego de veículos e especulação imobiliária proporcionaram uma forte redução no número de campos de várzea na cidade de São Paulo, embora se note uma quantidade expressiva destes na periferia metropolitana. Ao mesmo tempo, proliferam campos fechados, de acesso pago, de uso social muito restrito. E assim a grande metrópole de 17 milhões de habitantes apresenta uma produção de talentos futebolísticos

Giano (1999), e sobre o carioca, ver o livro de Pereira (2000).

21 O estádio do Pacaembu foi inaugurado em 1940, na gestão de Prestes Maia. Foi construído em concreto sobre uma grata inculta, aproveitando bem o vale (as arquibancadas laterais se ajustam à declividade do terreno, canalizando sob o estádio as nascentes do ribeirão) para traçar o projeto monumental de linhas expressionistas (REIS FILHO, 1994:181-185). Este aspecto de triunfo da engenharia humana sobre o sítio certamente impressionou Pierre Monbeig. Na pag. 45 de La Croissance de la Ville de São Paulo, um mapa da capital põe em destaque o estádio do Pacaembu. Sobre o contexto e o uso político da obra, e seu impacto na sociedade, ver o excelente artigo de Negreiros (1997).

22 Em 1954, o mesmo Monbeig já não vive mais no Brasil, mas publica um artigo em homenagem aos quatrocentos anos da cidade de São Paulo. O tom é ufanista, incansável no registro do triunfo da técnica e do trabalho coletivo sobre as várzeas, "que deixaram de ser manchas brancas no mapa". Exalta a rápida expansão urbana, a edificação de arranha-céus e de extensa malha viária, a aglomeração da indústria e do comércio, e não ignora o ambiente esportivo: esta cidade é o "grande teatro dos esportes" (MONBEIG, 1954: 147). Mas a modernização é sempre incompleta, e neste sentido Monbeig lamenta a persistência do "atraso", nele envolvendo mais uma vez o pequeno futebol popular. Entretanto, o autor reforça a esperança de superação definitiva deste cenário, ao afirmar que "as obras de retificação do Tietê contribuem para o seu saneamento e em breve deixarão de ser o refúgio de uma população um tanto à margem dos quadros normais: já não são o domínio exclusivo dos moleques fanáticos por futebol ou dos oleiros..”(MONBEIG, 1954:149, grifo nosso). Um estudo a respeito do olhar mobeigeano para o futebol na cidade de São Paulo encontra-se em Mascarenhas (1999b). 
que está bem aquém de seu porte demográfico. Mas estas são outras questões, sobre a cidade e o futebol, para além dos limites deste trabalho.

\section{CONCLUSÃO}

De um modo geral, o processo de introdução e difusão espacial do futebol no Brasil "obedeceu" à heterogeneidade da base territorial: a distribuição e a estrutura do sistema urbano, as conexões com o exterior, o dinamismo de cada cidade e particularmente a geografia do Imperialismo Britânico, que em determinado período imprimiu-se de forma destacada na composição técnica do território brasileiro. Somente num segundo momento, é que as metrópoles nacionais nascentes passaram a atuar como difusoras do futebol. Neste quadro, torna-se difícil precisar uma única ou principal "porta de entrada" do esporte das multidões no Brasil.

Supomos que cada cidade apresentou, de início, um grau próprio de "exposição" à informação (futebol). Tal grau de exposição dependeria, em última análise, da presença de ingleses, fixos (empresas atuantes) ou de passagem (comércio portuário, por exemplo). Foram os ingleses, portadores dos nexos globais, os agentes "demonstradores" desta novidade esportiva, e a presença maior ou menor destes agentes implica no grau de exposição do lugar. Por outro lado, é necessário que o lugar possua dinamismo/potencialidade de absorver a informação e transformala em sistemas de ações e de objetos. E nestes aspectos São Paulo se revelou com destaque.

Já nas últimas décadas do século XIX era muito intensa a vida esportiva paulistana (REIS FILHO, 1994; BRUNO, 1984:1215-46). Rapidamente o futebol ultrapassou os muros dos fechados recintos da colônia inglesa para ganhar os estabelecimentos escolares e clubes nacionais da burguesia, e a seguir as ruas. $\mathrm{O}$ fato desta cidade concentrar um crescente número de estabelecimentos industriais favoreceu a difusão do "futebol de fábrica", incentivado pelas próprias empresas, como forma de cooptação do trabalhador, fazendo-o vestir a camisa da empresa. Ao "contar" com a vastidão das várzeas como espaços intersticiais que durante muito tempo resistiram ao uso capitalista, a cidade permitiu a disseminação de campos de futebol informal, objetos geográficos que expressam e articulam uma vasta rede de bairros populares.

A partir da década de 1950, a especulação imobiliária e as constantes intervenções no espaço urbano, sobretudo aquelas dedicadas à modernização da malha viária a partir da retificação dos rios Pinheiros e Tietê, levaram à redução brutal da extensão das várzeas, tradicional espaço da cultura popular paulistana. Neste processo, o futebol varzeano sofreu irreversível encolhimento, mas persiste sobretudo na periferia metropolitana. São os excluídos da urbe, que se apropriam de terrenos baldios para iluminar, aos dribles, este lado escuro da metrópole.

Resumo: No sentido de abrir uma nova perspectiva de estudo geográfico da cidade, procuramos inserir o futebol. Trata-se de modalidade esportiva codificada pelos ingleses no século XIX e que rapidamente se difundiu no contexto da modernidade urbana, alimentando a cultura operária em formação. Analisando o caso brasileiro, procuramos examinar o processo de popularização do futebol na cidade de São Paulo.

Palavras-chave: futebol — cidade — classe operária — Brasil

Abstract: In order to open a new perspective on geographical studies of the city, we try to insert the football. This sport was codified by the English in the nineteenth century and quickly spread out in the modernity context, contributing to the making of the working class culture. Analysing the Brazilian situation, we examine the popularisation process of the football in São Paulo.

Key — words: football — city — working class - Brazil

\section{BIBLIOGRAFIA}

ANTUNES, Fátima Martin (1992). Futebol de Fábrica em São Paulo. Dissertação de Mestrado em Sociologia, FFLCH-USP.

(1998). Do velódromo ao Pacaembu: o movimento esportivo em São Paulo e a trajetória do futebol, de esporte de elite a paixão nacional. Revista do Departamento de Patrimônio Histórico, São Paulo, ano v, n.5, jan. 1998, pp.88-95.

AZEVEDO, Aroldo de (1958). A Cidade de São Paulo: Estudos de Geografia Urbana. São 
Paulo: Cia. Ed. Nacional.

BOAVENTURA, João C. Sociologia Desportiva: o Tailorismo no Futebol. Futebol em Revista, Lisboa, Federação Portuguesa de Futebol, ed. Perspectivas e Realidades, s/d.

BROHM, Jean-Marie (1998). Le spectacle du football impérialiste. In: Les shootés du Stade. Paris: Èditions Paris-Méditerranée.

BRUNO, Ernani. (1984). História e Tradições da Cidade de São Paulo. Volume II: Burgo de Estudantes, e Volume III: A Metrópole do Café. São Paulo: Hucitec e Secretaria Municipal de Cultura.

BUYTENDIJK, F.J. (1965) Psicologia do futebol. São Paulo: Herder.

BUZZETTI, Jose Luis. La Nacionalización del Futbol, in (1969) (org.) El fútbol: antología. Montevideo: Centro Editor de América Latina.

CALDAS, Valdenyr (1990). O Pontapé Inicial: Memória do Futebol Brasileiro (1894 - 1933). São Paulo: IBRASA.

CONDEPHAAT (Conselho de Defesa do Patrimônio Histórico, Arqueológico, Artístico e Turístico do Estado de São Paulo) (1994). A geografia do futebol de várzea em São Paulo. In: Estudo do tombamento do Parque do Povo. S. Paulo.

DA MATTA, Roberto e outros (1982). O Universo do Futebol: Esporte e Sociedade Brasileira, Rio de Janeiro, Edições Pinakotheke.

DAMO, Arley Sander (1998). Para o que der e vier. O pertencimento clubístico no futebol brasileiro a partir do Gremio de Football Portoalegrense e seus torcedores. Dissertação de mestrado em Antropologia Social, UFRGS.

DI GIANO, Roberto.(1999) El Fenomeno Migratório y el Fútbol. LECTURAS: Educación Física y Deporte (revista digital), Buenos Aires, 13, aflo III, marzo/1999.

FONTENELLE, André (1997). História do Campeonato Paulista. São Paulo: PubliFolha.

FRYDENBERG, Julio David. Espacio urbano y practica del fútbol: Buenos Aires 1900 - 1915. LECTURAS: Educación Física y Deporte (revista digital), Buenos Aires, num 13, año III, marzo/1999.

GUEDES, Simoni (1998). O Brasil no Campo de Futebol: estudos antropológicos sobre os significados do futebol brasileiro. Niterói: EDUFF.

GUTTMANN, Alien (1994). Games and Empires: modern sports and cultural imperialism. N.York: Columbia University Press. 275 p.

HOBSBAWM, Eric (1989). Nações e nacionalismos desde 1870. São Paulo: Paz e Terra, 1991. (1987). Mundos do Trabalho. Novos estudos sobre História operária. São Paulo: Paz e Terra.

MASCARENHAS, Gilmar (2002). O lugar e as redes: futebol e modernidade na cidade do Rio de Janeiro. In: MARAFON, G. e RIBEIRO, M. (orgs.) Estudos de Geografia Fluminense. Rio de Janeiro: Infobook, pp. 127-142.

(2001). A bola nas redes e o enredo do lugar Uma geografia do futebol e de seu advento no Rio Grande do Sul. Tese de doutorado em Geografia Humana, Universidade de São Paulo.

(2000). Considerações teórico-metodológicas sobre a difusão do futebol. Scripta Nova - Revista Electrónica de Geografia y Ciencias Sociales, Universidade de Barcelona, vol. 4, numero 69 (23), agosto de 2000. www.ub.es/geocrit.

(1999). Mundo e Lugar: a Introdução do Futebol no Brasil Urbano. Experimental, (revista do Laboratório de Geografia Política e Planejamento Territorial e Ambiental da USP), ano III, 6, março de 1999, pp. 95-110.

(1999). Semeando no deserto: a cidade e o futebol emPierre Monbeig. In: I Encontro

Nacional de História do Pensamento Geográfico, eixos temáticos vol. 1, pp.53-60, Rio Claro: UNESP, $1999 b$.

(1998). Construindo a "Pátria de Chuteiras": elementos para uma Geografia da difusão do futebol no Brasil. In: SCHÄFFER, Neiva et al (orgs.) Ensinar e Aprender Geografia. Porto Alegre: AGB, pp. 93-103.

(1998). Futbol y Modernidad en Brasil: la geografía historica de una novedad.

LECTURAS: Educación Física y Deporte (revista eletrônica., meio digital), num 10, año III, mayo/1998, Buenos Aires. 
MARTIN, André (1984). O Bairro do Brás e a Deterioração Urbana. Dissertação de mestrado em Geografia Humana, FFLCH-USP.

MASON, Tony (1995). Passion of the people? Football in South America. London: Verso. (1980). Association Football and English Society (1863-1915) Brighton: The Harvester Press.

MAZZONI, Thomaz (1968). "Futebol Pioneiro e Bandeirante". In: Octávio FARIA (org.) O ôlho na bola. Rio de Janeiro: Livraria-editora Gol. (1950). História do Futebol no Brasil. São Paulo: Ceia.

MELO, Victor (1999). "Cidade Sportiva": o turfe e o remo no Rio de Janeiro (1849-1903). Tese de doutorado em Educação Física, Universidade Gama Filho.

MERCIER, Joseph (1966). Le Football,. Paris: Presse Universitaire de France.

MONBEIG, Pierre (1954). Aspectos geográficos do crescimento de São Paulo. Boletin Geográfico, 12(119), 1954, pp 139-153.

(1953). La Croissance de la Ville de São Paulo. Grenoble: Institut et Revue de Géographie Alpine.

NEGREIROS, Plinio (1997). O estádio do Pacaembu. Coletânea do V Encontro de História do Esporte, Lazer e Educação Física, Ijuí: Editora da UNIJUÍ, pp. 31-44.

(1992). Resistência e rendição: a gênese do Sport Club Corinthians Paulista e o futebol oficial em São Paulo. Dissertação de mestrado em História Social, PUC-SP.

PAOLI, M. Célia (1990) São Paulo Operária e suas Imagens (1900 - 1940), Revista Espaço e Debates 33, São Paulo, NERU.

PEREIRA, Leonardo A. (2000) Footballmania: uma história social do futebol no Rio de Janeiro, 1902-1938. Rio de Janeiro: Nova Fronteira, 374p.

RAMOS, Roberto (1984). Futebol: Ideologia do Poder. Petrópolis: Vozes.

REIS FILHO, Nestor Goulart (1994). São Paulo e Outras Cidades, São Paulo, Hucitec, Col. Estudos Urbanos n. 5.

ROSENFELD, Anatol (1993). Negro, Macumba e Futebol. São Paulo, EDUSP / Unicamp / Perspectiva, Coleção Debates vol. 258.

SANTA CRUZ, Eduardo (1996). Origen yfuturo de una passión: futbol, cultura y modernidad. Santiago: LOM - ARCIS.

SANTOS, Milton (1994). Técnica, Espaço e Tempo: Globalização e Meio Técnico Científico Informacional. São Paulo: Hucitec.

SEBRELI, Juan (1981). Fútbol y masas. Buenos Aires: Editorial Galerna.

SEABRA, Odette C.L (1987). Meandros dos Rios nos Meandros do Poder Tietê e Pinheiros: Valorização dos Rios e das Várzeas na Cidade de São Paulo. Tese de Doutoramento em Geografia Humana apresentada à FFLCH - USP. pp.11-17.

(2000). Urbanização: bairro e vida de bairro. Travessia, São Paulo, set./ dez. 2000,

SEVCENKO, Nicolau (1994) Futebol, Metrópoles e Desatinos, Revista USP (Dossiê Futebol), São Paulo, num.22, jun/jul/ago de 1994.

(1992) Orfeu Extático na Metrópole: São Paulo, Sociedade e Cultura nos Frementes Anos 20. São Paulo, Cia. das Letras.

SINGER, Paul (1974). Desenvolvimento Econômico e Evolução Urbana. São Paulo, Cia. Ed. Nacional.

SURUBU, Nilo (1963). Fútbol, pasión del mundo. Montevideo: Gráfica Berches.

VILLORO, Juan. (1998) Los goles y ei tiempo. Revista Nueva Sociedad, 154, mar-abr 1998, pp. 58-65.

VINNAI, Gerhard (1974). El Fútbol como Ideología. Madrid: Siglo Veintiuno. 